\title{
Porto e meio ambiente: apresentação
}

As mudanças na economia globalizada sugerem que as práticas e demandas da sociedade brasileira sejam repensadas, buscando-se novas alternativas sociais e econômicas que viabilizem o desenvolvimento do país. Esse processo de mudança passa tanto pelo conhecimento, pela tecnologia e pela infra-estrutura, quanto por vários meios de preservação e desenvolvimento social. Este número da Revista de Administração Pública (RAP) traz uma nova contribuição, enfocando o debate sobre o porto e o meio ambiente.

O porto é um meio eficaz para o desenvolvimento da economia do país, mas não no Brasil, onde o transporte portuário só recentemente passou a ocupar espaço na agenda governamental. O mesmo se pode dizer da gestão ambiental, que constitui um dos graves problemas do país, destruindo parte significativa do patrimônio ambiental e dos recursos naturais.

Daí a importância de trazer para o debate a questão portuária e ambiental, as relações que se estabelecem entre porto e cidade, pois a dinâmica do porto, o movimento da carga, o processo de exportação e importação determinam as condições do espaço urbano. Esse processo se reflete no meio ambiente e na realidade marítima, fazendo com que os autores dos artigos deste número da RAP lancem olhares diferentes sobre as questões portuárias e ambientais.

$\mathrm{O}$ artigo de Monié e Vidal, que dá início à $R A P$, começa com a discussão sobre a evolução das relações cidades/portos e a reorganização dos espaços produtivos, que ocasionam um conjunto de mudanças na estrutura mundial dos portos. O transporte marítimo sempre esteve associado ao aumento da capacidade dos navios, por ganhos em velocidade e pela diminuição significativa do custo do frete. A partir dos anos 1990, com a intensificação do processo de globalização, novas demandas foram colocadas sobre os portos. No caso do Brasil, as inovações institucionais e a governança portuária exigem mudanças e uma nova cultura portuária, que transforme os portos em vetores de desenvolvimento.

Tais transformações demandam a modernização portuária e dos sindicatos dos trabalhadores portuários. Nesse sentido, Aguiar, Junqueira e Freddo fazem uma reflexão sobre o papel do sindicato dos estivadores da cidade 
de Santos no processo de modernização do porto. Discute-se a importância do porto no passado e no presente, a história do sindicato no século XX e seu posicionamento no processo de modernização portuária. Procuram compreender a relação porto de Santos e sindicato dos estivadores, buscando visualizar o papel desses atores na evolução socioeconômica da cidade de Santos.

As atividades portuárias remetem para os conflitos ambientais e sua gestão. Nessa perspectiva se situa o artigo de Cunha, que discute o porto como objeto de atenção da política ambiental brasileira. Por seu papel indutor de transformações territoriais em ampla escala, inúmeros conflitos ambientais ocorrem associados a essas atividades. A agenda ambiental portuária surge como iniciativa voltada a promover planos de gestão pactuados entre os atores locais.

Ainda discutindo a gestão ambiental e portuária no Brasil, Kitzmann e Asmus visualizam os desafios do processo de reformas portuárias implementadas pela Lei de Modernização dos Portos (Lei no 8.630/93). O foco fica na gestão ambiental, não adequadamente incorporada ao sistema portuário brasileiro, e nas iniciativas de planejamento portuário, que consideram a regulamentação ambiental como um fator que ameaça a competitividade das empresas. Esse artigo defende a idéia de que a adequação às normas ambientais traz oportunidades de melhoria para o negócio portuário. A gestão ambiental vai além da gestão dos problemas rotineiros, incorpora-se à macroescala, à gestão da zona costeira, para que o novo modelo portuário seja economicamente competitivo e com benefícios socioambientais.

Outra discussão da gestão ambiental é feita por Velásquez, Villas Boas e Schwartzman, no artigo que apresenta a gestão ambiental integrada em território de fronteira agrícola no oeste do Pará. O foco é numa região brasileira localizada em um dos estados mais conflituosos da Amazônia. Converte-se em um desafio simbólico para a gestão pública integrada, uma vez que traz em seu contexto político elementos característicos de um sistema altamente complexo como a grilagem de terras e a exploração irracional dos recursos naturais. O desafio da gestão ambiental integrada no território da Terra do Meio reflete sobre o preparo e habilidades dos gestores públicos e da sociedade civil no enfrentamento das questões ambientais e das diferentes arenas sociais que existem nos diversos contextos da Região Amazônica.

Finalmente, a gestão ambiental é vista pela ótica contábil. Tinoco e Robles discutem a contabilidade da gestão ambiental e a transparência empresarial, contemplando quatro empresas brasileiras com atuação global. Realizam um estudo exploratório que identifica a sustentabilidade econômica e o desenvolvimento social para apoiar decisões gerenciais e a comunicação das ações empresariais. 
Outra dimensão da sustentabilidade é a gestão das águas. O artigo de Baraglio e Warner trata da hidropolítica e o federalismo das possibilidades de construção de um modelo de subsidiariedade na gestão das águas no Brasil, considerando os 26 estados e mais de 5.500 municípios, além do Distrito Federal. Como o sistema político do país se relaciona com os fóruns da água, indaga-se quais seriam as variáveis essenciais que precisam ser consideradas na discussão da água como um bem público, que afeta a vida cotidiana de milhões de pessoas. Daí a necessidade de ser construído um federalismo de cooperação que alavancará a subisidiariedade na gestão das águas.

Por fim, o artigo de Cardoso traz uma discussão que difere do objeto que pautou a maioria dos artigos até então. Aborda a questão dos desafios da comunicação empresarial e organizacional. Debate os processos comunicativos relevantes no ambiente das organizações, principalmente em situações complexas. O autor centra em um novo conceito de comunicação organizacional, analisando os fundamentos teóricos da comunicação de Habermas e Cohn, bem como as contribuições do teórico da complexidade, Genelot, buscando superar os limites dos enfoques reducionistas do conceito tradicional de comunicação empresarial.

A maioria dos artigos aqui apresentados pretende contribuir para o entendimento das questões que alimentam o debate sobre a problemática do porto e meio ambiente. São questões que demandam diversos olhares e saberes, que possibilitam a compreensão interdisciplinar do porto e do meio ambiente, encaminhando soluções que integrem a gestão portuária e ambiental, tornando-as mais eficazes e eficientes para o desenvolvimento do país. 